\title{
Development of Entrepreneurial Spirit and Women Empowerment at Pesantren Griya Khadijah Surabaya through Diversification Training on Fishery Products as Food Commodities with High Nutritional Value
}

\author{
Author \\ Putri Desi Wulan Sari (ORCID ID 0000-0001-8832-113X) \\ Luthfiana A. Sari (ORCID ID 0000-0001-7387-9958) \\ Rahayu Kusdarwati (ORCID ID 0000-0001-6281-6177)
}

\author{
Correspondence \\ Department of Aquaculture, Faculty of Fisheries and Marine, Universitas Airlangga, Surabaya 60115 \\ putri.dw@fpk.unair.ac.id
}

\begin{abstract}
:
The development of an entrepreneurial spirit can be started even with minimal capital. Fishery products with high nutritional value are one of the opportunities that can be developed by community groups as independent businesses in the context of increasing the economy. Santriwati at the Griya Khadijah Islamic Boarding School Surabaya is a national asset that has great potential, role, and opportunity in influencing the social and economic life of the surrounding community. This community service activity aims to improve the competence of female students at the Griya Khadijah Islamic Boarding School, as a role model for hafidzah-preneur education, to be able to develop an entrepreneurial spirit and reflect women's empowerment with good character.
\end{abstract}

Keywords : Entrepreunership. Woman Empowerment. Fishery Product. Community.

\section{Introduction}

Fish are all types of organisms that all or part of their life cycle is in the aquatic environment (Law Number 45 of 2009). Based on the report on the value and contribution of the 2015 fisheries sector category, as many as IDR $750,070,80$ (million) or $0.18 \%$ of business fields in the fisheries, agriculture and forestry sectors. Fish is high in nutrition, has good protein and is low in cholesterol. Consumption of fish can be useful for preventing arteriosclerosis because of the high content of omega-3 unsaturated fatty acids and turin.

According to economic performance in Surabaya; as much as 79,334,006, 90 (million Rupiah) or $19.46 \%$ of the business sector in the processing industry contributes to the economy in Surabaya. This can be interpreted that the combination of the fisheries sector in the processing industry has great prospects in moving the community's economy.

In 2019, the achievement of numbers of fish consumption in East Java still reaches $38.82 \mathrm{~kg}$
Received: 05 August 2021. Accepted: 21 December 2021.

per capita per year. This figure is real is still smaller than that of countries with productive populations, so that more massive efforts are still needed to increase fish consumption through value-adding added to fishery products. Food diversification or diversification is one of the efforts to increase community fish consumption (Center for Marine and Fishery Education, 2015). Diversification aims to meet the diverse tastes of consumers and continues to grow so that there are always alternatives and menu refreshments. In addition to this, diversification is also an effort to increase market absorption to provide opportunities for fishery product processors to develop their businesses (Agustini and Swastawati, 2003).

Today, with the advancement of technology, the era of globalization, food fashion trends make it easier for processed fishery products to spread widely from one area to another, even widely spread globally. The trend of food sourced from fish raw materials in the form of snacks (snacks) and large meals requires business actors in the field of fisheries to be more creative and 
innovative in developing processed fishery products. The existence of potential development and demands for processed fishery products can be used as a state of problem in pioneering an independent business (entrepreneur) in the field of fisheries. The progress in the digital era has made it easier for independent business actors to be able to market their processed products so that they can be widely spread both on a national and international scale.

Moreover, the marine and fisheries sector is one of the priority commodities in the development of cooperatives and micro scale of business that can support Indonesia's economic progress to become the world's top five economies by 2030 (Media Indonesia, 2020; Liputan 6, 2020)

Griya Khadijah Islamic Boarding School is a boarding school as a form of Amerta Waqf management. As a form of Amerta Waqf management, then Nazhir Universitas Airlangga developed one model of productive waqf management, namely The Griya Khadijah Program. Griya Khadijah is a student development program sustainable, with an output target of at least 5 juz hafiz, noble character, and soulful entrepreneur. The Griya Khadijah program provides residential dormitory facilities along with assistance for selected people to be guided in achieving their goals in the future and contribute to the Education Development program. According to the achievement of Sustainability Development Goals, santriwati who has joined the Griya Khadijah Family, will guided in a dormitory with tahfidz and entrepreneur knowledge. Expectations from the implementation of the program Griya Khadijah is the birth of a hafidzah-preneur (who is able to memorize the Qur'an), also for entrepreneurship who will help the environment around them by the knowledge they have gained, both the science of tahfidz (read the Qur'an) and the science of entrepreneurship. Griya Khadijah is located in Tambaksari District, Surabaya City, which is one of the one sub-district in the city of Surabaya which is included as a community group has the potential to be developed.

Women are the part of the society. In the other side, they have less authority. Society cannot be created without women contribution. Women should be empowered because both men and women are human beings and are equal. Women empowerment includes women awareness of their rights, self-confidence, to have a control over their lives both at home and outside and their ability to bring a change in the society, contribute to the economy, societes and countries (Sohail, 2014). Women also have benefited in economic and social development in the last three decades. They continue to be overrepresented among the world's most vulnerable groups, as access to resource and power remains highly skewed towards men. Women's empowerment gaining more power and control over their own lives. This entails the idea of women's continued disadvantage compared to men which is apparent in different economic, sociocultural and political spheres (Lohani and Aburaida, 2017).

The purpose of community service activities in Tambaksari District with a pilot model at the Griya Khadijah boarding school is to provide a focus learning center to increase public knowledge of independent business efforts (entrepreneurs) in the fisheries and marine sector through empowering women workers in creating fishery product diversification.

\section{Methods}

The implementation of activities is carried out with a participatory approach and through the provision of counseling on the topic of entrepreneurship and diversification of fishery products. online training related to the preparation of the business model canvas (BMC). The participatory approach is often used in activities related to community empowerment. Workshops and demonstrations on the practice of diversifying fishery products were held on the date through webinars that are open to the public as well as assistance to a group of people on the processing of fishery products.

Community service activities are divided into two group of activitiy. The first activity is the provision of entrepreneurship materials to increase public interest in creating digital-based independent businesses. The second activity is carried out in the form of counseling with the topic of introducing important economic value of fishery products that can be diversified into high selling value products. 


\section{Result and Discussion}

The initial stage of this community service activity was started with a survey of community characteristics and development analysis that can be applied to advance the community's economy at the service location. The survey activity was preceded by a search for population data and literature studies to update training materials regarding the development of independent businesses in the field of fisheries. The target audience of this community service program are Muslim women at the Griya Khadijah Islamic Boarding School. The existence of training for Muslim women in Islamic boarding schools is expected to be a good model for the surrounding community, considering the function of Islamic boarding schools is as a place to shape the character of the next generation of noble character.

Based on the results of surveys and interviews with Muslim women in Islamic boarding schools, it is known that there is potential for Muslim women in Griya Khadijah Islamic boarding schools to develop independent businesses. This can be seen from the existence of Muslim women who have independent sales businesses with small business fields. For example, there are Muslim women who work as resellers through online sales platforms. The general obstacle that is felt is that knowledge about innovation and mapping of market needs is still low, so that the field of working on independent business for Muslim women does not yet have the diversity and digitalization needed in the industrial era 4.0 and the current era of society 5.0, as well as the lack of business capital to develop creativity in entrepreneurship. independent.

Following up on the potential for developing independent businesses from Muslim women at the Griya Khadijah Islamic boarding school, a socialization was held about building a digital startup mindset with minimal capital. The provision of information is carried out by modeling material presentation in class by digital startup experts and assisting startup digitization. This activity begins with the presentation of material about the urgency of digital marketing needs and how to grow ideas in building independent businesses through digital marketing.
Digital marketing is the most widely used marketing system by business people today. In the current era, digital marketing is considered the most effective tool for marketing products and services. In the use of digital marketing, entrepreneurs feel benefited because they have no limitations in the use of devices for promotional media, such as mobile phones, tablets, laptops, television, social media, SEO, video, email, and so on (Sabila, 2019). The use of online media is the right choice for business actors to develop their business (Wardhana, 2015). According to Rapitasari (2016), analysis of internal and external aspects is needed in determining digital marketing strategies. Several steps can be taken to compile the analysis, among others, by identifying the business, identifying competitors, customers, business targets and programs that need to be run.

An entrepreneur should have an agile mentality to be able to focus on one product development feature, validate the product being developed and apply scalability to the product being marketed. Agile itself is defined as the ability to make and respond to changes in an uncertain environment (Sujono et al., 2020). Agile methods are believed to be able to speed up the development of a product.

The presentation related to digital marketing and starting a business with minimal capital was enthusiastically followed by all participants. Several questions were asked by participants during the discussion session, related to strategies to maintain business in the midst of many competitors, the marketing cycle in digital marketing, and validation methods in the digital startup business.

The second stage of community service activities is the provision of material on fishery products that can be diversified into food products with high nutritional value. Before presenting the material on fishery product diversification, participants were introduced to how to recognize the freshness of fish. This is intended so that community groups can identify fresh fish that are worthy of being selected to be processed into food products of high economic value. This activity was followed by a fairly high enthusiasm of the participants.

Fish freshness is a very important factor and is closely related to fish quality. The freshness 
of the fish determines the quality of the food. The characteristics of good fresh fish are:

1. Clear fish eyes, clear cornea, black bulbs and convex eyes

2. Fresh red gills, has decreased in quality will cause the gills to be gray, slimy and smelly

3. The mucus is clear and smells fishy. If it has rotted, the mucus becomes yellowish, sticky and has a pungent smell

4. The fish sticks firmly, shiny and covered with clear mucus. If it's not fresh, the scales will easily fall off and the color will fade

5. The smell of fresh fish smells typical of fish. If it is not fresh, the fish will emit a bad smell and float if placed in water

6. Fresh fish flesh is elastic and brightly colored. If pressed does not cause permanent scars. Busk fish is pale in color, soft and leaves permanent traces when pressed

After the participants know how to recognize fresh fish, the next activity is a demonstration of variations in milkfish processing. Milkfish (Chanos Chanos) is a fishery commodity that is very popular with the public, especially adult milkfish, besides being widely available in the market, strategic commodity in supporting food security and nutrition community, also have affordable prices.

The practice of processing milkfish is also carried out to provide a real picture to the community about how to process milkfish into ready-to-consume products or frozen ready-to-sell forms. In addition to demonstrations and practices on milkfish processing, community groups are also introduced to various attractive forms of presentation, so that the fish products sold can be displayed in attractive packaging for buyers. The level of participation and enthusiasm of the community group was quite good, judging from the active participation of the participants during the event. It is hoped that this activity will increase the competence of community groups, especially women, in improving the economy and providing high nutritional value food from fish.

\section{References}

Agustini, T.W. dan F. Swastawati. 2003. Pemanfaatan Hasil Perikanan Sebagai Produk Bernilai Tambah (Value-Added) dalam Upaya Penganekaragaman Pangan. Jurnal Teknologi dan Industri Pangan, 14(1). 72-81.

Liputan 6. Produk Perikanan Indonesia Ditargetkan Kuasai Dunia pada 2024. https://www.liputan6.com. Accessed on July, $20^{\text {th }} 2021$

Lohani, M., and L. Aburaida. 2017. Women Empowerment : A Key to Sustainable Development. The Social Ion, 6(2) : 26-29.

Marine Education Center and Fishery. 2015. Membuat Diversifikasi Produk Perikanan. Pusat Pendidikan Kelautan dan Perikanan. Jakarta. $128 \mathrm{p}$

Media Indonesia. 2020. Produk Perikanan Indonesia Makin Diminati Dunia. https://mediaindonesia.com. Accessed on July, $26^{\text {th }} 2021$

Sabila, Nur. 2019. Pengantar Digital Marketing. Stekom. Semarang. $69 \mathrm{p}$

Sohail, M. 2014. Women Empowerment and Economic Development - An Exploratory Study in Pakistan. Developing Country Studies, 4(9) : 163-171.

Sujono, S., M.A. Setiawan, K. Haryono. 2020. Tantangan Adopsi Agile di Perguruan Tinggi Indonesia. Jurnal Informatika, 8(2) : 197-206.

Rapitasari, D. 2016. Digital Marketing Berbasis Aplikasi Sebagai Strategi Meningkatkan Kepuasan Pelanggan. Jurnal Cakrawala, 10(2) : 107-112.

Realita, F.Y. Ade, Dahlia. 2016. Jenis-Jenis Ikan Segar yang Diperdagangkan di Pasar Modern Kabupaten Rokan Hulu Provinsi Riau. Unpublished). 
Wardhana, A. 2015. Strategi Digital Marketing dan Implikasinya pada Keunggulan Bersaing UKM di Indonesia. Prosiding Forum Keuangan dan Bisnis IV. 327-337

https://creativecommons.org/licenses/by-nc/4. 